\title{
Parasitic Fauna of Some Macrouridae in the Northwest Atlantic
}

\author{
A. V. Zubchenko \\ Polar Research Institute of Marine Fisheries and Oceanography (PINRO) \\ 6 Knipovich Street, Murmansk, USSR
}

\begin{abstract}
The parasitic fauna of three species of grenadier in the Northwest Atlantic revealed 33 species of parasites related to seven taxonomic groups: Myxosporidia, Monogenoidea, Cestoda, Trematoda, Nematoda, Acanthocephala and Crustacea. Roundnose grenadier, Coryphaenoides rupestris Gunnerus, from Davis Strait, Labrador and northern Grand Bank were infested by 14 species of parasites, half of which occurred in all three areas. The greater incidence of infestation by parasites whose intermediate hosts are pelagic animals indicate that the latter form a significant part of the diet. The roughhead grenadier, Macrourus berglax Lecepede, from Flemish Cap and northern Grand Bank were infested by a diverse group of 21 species of parasites, many of which are the intermediate hosts of benthic animals and fish. The common grenadier, Nezumia bairdi Goode and Bean, from Flemish Cap and northern Grand Bank were infested by 11 species of parasites whose intermediate hosts are mainly planktonic organisms. Very distinct between-area differences in parasitic infestation of the latter two species of grenadier indicate that the samples were from separate populations. Myxosporidian spores were found in one specimen of Chalimura brevibarbis caught on Flemish Cap.
\end{abstract}

\section{Introduction}

Ecological studies on Macrouridae are difficult due to the great depths at which these fish live, and thus it is not surprising that information on the parasitic fauna of this group of fishes in the Northwest Atlantic is rather scanty. Wilson (1920) found the copepod Chondracantus radiatus in roundnose grenadier, Coryphaenoides rupestris. More recently, this fish was found to be infested by Dolichoenterum sp. and Gonocerca crassa (Szuks, 1975), and by Myxidium melanostigmum, M. melanocetum, M. profundum, Zschokkella hildae, Auerbachia sp., Diclidophora macruri, Scolex pleuronectis I., Bothriocephalus sp., Hemiurus macrouri, Derogenes varicus, Gonocerca macrouri, Aporocotyle simplex, Contracaecum aduncum, and Anisakis sp. (Zubchenko, 1976, 1981; Zubchenko and Krasin, 1980). The parasites of roughhead grenadier, Macrourus berglax, are known to include Sphyrion lumpi (Templeman and Squires, 1960), Clavellomimus macruri (Kabata, 1969), Eineria sp., Glugea berlgax, Myxidium melanostigmum, $M$. melanocetum, Auerbachia pulchra and Davisia newfoundlandia (Yoshino and Noble, 1973; Lom et al., 1975; Lom and Laird, 1976; Moser, 1977; Moser and Noble, 1977a; Zubchenko and Krasin, 1980; Gayevskaya et al., 1980). The common grenadier, Nezumia bairdi, is known to be infested by the parasites Auerbachia pulchra and Zschokkella globulosa (Moser and Noble, 1977a, 1977b).

All of the papers mentioned above deal mainly with systematics. This paper presents data on the parasitic fauna of three species of grenadier commonly found in the Northwest Atlantic and considers the ecological implications.

\section{Materials and Methods}

The fish specimens were collected during 1974-79 from various areas of the Northwest Atlantic extending from Davis Strait to the northern slope of Grand Bank and Flemish Cap. A total of 353 specimens of three species of grenadiers, Coryphaenoides rupestris (300), Macrourus berglax (30) and Nezumia bairdi (23), were examined by the method of complete parasitological dissection (Dogiel, 1933). One specimen of Chalinura brevibarbis from the Flemish Cap area was also examined.

\section{Results and Discussion}

Parasitological investigation of 353 specimens of three species of Macrouridae (roundnose grenadier, roughhead grenadier and common grenadier) revealed 32 species of parasites related to seven taxonomic groups: Myxosporidia (7), Monogenoidea (2), Cestoda (4), Trematoda (10), Nematoda (4), Acanthocephala (1), and Crustacea (4).

\section{Roundnose grenadier, Coryphaenoides rupestris}

Eighteen species of parasites were found in the 300 specimens of roundnose grenadier examined (Table 1), of which eight species in three groups (Myxosporidia, Monogenoidea and Crustacea) have a direct 
TABLE 1. Parasitic fauna of roundnose grenadier, Coryphaenoides rupestris, in the Northwest Atlantic.

\begin{tabular}{|c|c|c|c|c|c|c|c|c|c|c|c|c|c|c|c|}
\hline \multirow[b]{3}{*}{ Parasites } & \multicolumn{5}{|c|}{ Davis Strait (105 spec.) } & \multicolumn{5}{|c|}{ Labrador (105 spec.) } & \multicolumn{5}{|c|}{ N. Grand Bank (90 spec.) } \\
\hline & \multicolumn{2}{|c|}{$\begin{array}{c}\text { Specimens } \\
\text { infested }\end{array}$} & \multicolumn{3}{|c|}{$\begin{array}{l}\text { Intensity of } \\
\text { infestation }\end{array}$} & \multicolumn{2}{|c|}{$\begin{array}{c}\text { Specimens } \\
\text { infested }\end{array}$} & \multicolumn{3}{|c|}{$\begin{array}{l}\text { Intensity of } \\
\text { infestation }\end{array}$} & \multicolumn{2}{|c|}{$\begin{array}{l}\text { Specimens } \\
\text { infested }\end{array}$} & \multicolumn{3}{|c|}{$\begin{array}{l}\text { Intensity of } \\
\text { infestation }\end{array}$} \\
\hline & No. & $\%$ & Min & Max & Mear: & No. & $\%$ & Min & Max & Mean & No. & $\%$ & Min & $\operatorname{Max}$ & Mean \\
\hline \multicolumn{16}{|l|}{ Myxosporidia } \\
\hline Auerbachia pulchra & 91 & 86.7 & + & + & + & 49 & 46.7 & + & + & + & 46 & 51.1 & + & + & + \\
\hline Myxidium melanocetum & - & - & - & - & - & 4 & 3.8 & + & + & + & 17 & 18.9 & + & + & + \\
\hline Myxidium melanostigmum & 38 & 36.2 & + & + & + & 37 & 35.2 & + & + & + & 37 & 41.1 & + & + & + \\
\hline Myxidium profundum & 16 & 15.2 & + & + & + & 14 & 13.3 & + & + & + & 16 & 17.8 & + & + & + \\
\hline Zschokkella hildae & - & - & - & - & - & 1 & 1.0 & + & + & + & - & - & - & - & - \\
\hline \multicolumn{16}{|l|}{ Monogenoidea } \\
\hline Diclidophora macruri & 15 & 14.3 & 1 & 3 & 0.2 & 28 & 26.7 & 1 & 5 & 0.5 & 1 & 1.1 & 1 & 1 & + \\
\hline \multicolumn{16}{|l|}{ Cestoda } \\
\hline Philobythos atlanticus & 34 & 32.4 & 1 & 2 & 0.4 & 25 & 23.8 & 1 & 3 & 0.3 & 18 & 20.0 & 1 & 2 & 0.3 \\
\hline Pseudophyllidea gen. sp. & 3 & 2.9 & 1 & 1 & + & - & - & - & - & - & - & - & - & - & - \\
\hline Scolex pleuronectis 1. & 7 & 6.6 & 1 & 2 & 0.1 & 2 & 1.9 & 1 & 2 & + & - & - & - & - & - \\
\hline \multicolumn{16}{|l|}{ Trematoda } \\
\hline Aporocotyle simplex & - & - & - & - & - & 3 & 2.9 & 1 & 1 & + & - & - & - & - & - \\
\hline Derogenes varicus & - & - & - & - & - & 1 & 1.0 & 1 & 1 & + & - & - & - & - & - \\
\hline Glomericirrus macrouri & 8 & 7.6 & 1 & 2 & 0.1 & 9 & 8.6 & 1 & 2 & 0.1 & 12 & 13.3 & 1 & 2 & 0.2 \\
\hline Gonocerca macroformis & - & - & - & - & - & 1 & 1.0 & 1 & 1 & + & - & - & - & - & - \\
\hline Gonocerca macrouri & 13 & 12.4 & 1 & 3 & 0.2 & 21 & 20.0 & 1 & 84 & 1.2 & 24 & 26.7 & 1 & 12 & 0.8 \\
\hline \multicolumn{16}{|l|}{ Nematoda } \\
\hline Anisakis sp. I. & 1 & 1.0 & 1 & 1 & + & 16 & 15.2 & 1 & 3 & 0.2 & 3 & 3.3 & 1 & 2 & + \\
\hline Contracaecum aduncum & 1 & 1.0 & 1 & 1 & + & - & - & - & - & - & - & - & - & - & - \\
\hline Contracaecum aduncum I. & 1 & 1.0 & 1 & 1 & + & 4 & 3.8 & 1 & 2 & + & 3 & 3.3 & 1 & 2 & + \\
\hline \multicolumn{16}{|l|}{ Crustacea } \\
\hline Chondracantus radiatus & - & - & - & - & - & 1 & 1.0 & 1 & 1 & + & - & - & - & - & - \\
\hline Clavella adunca & - & - & - & - & - & 9 & 8.6 & 1 & 1 & 0.1 & 3 & 3.3 & 1 & 1 & + \\
\hline
\end{tabular}

life cycle. Myxosporidia and Trematoda (5 species each) were the most widely represented groups. The incidence of infection was highest for Auerbachia pulchra in all areas (47-87\%) and somewhat less for Myxidium melanostigmum (35-41\%) and Philobythos atlanticus (20-32\%). Among the parasites found, four species (Myxidium profundum, Diclidophora macruri, Glomericirrus macrouri and Gonocerca macrouri) are specific to Macrouridae, and four species (Myxidium melanocetum, M. melanostigmum, Auerbachia pulchra and Philobythos atlanticus) are specific to deepwater fish only. These eight parasites characterize the parasitic fauna of roundnose grenadier, the remaining 10 species of parasites being common to a large variety of hosts which live at shallower depths.

The presence of parasites with a complex cycle of development indicates that roundnose grenadier feed both on pelagic animals, which are connected with the development of the cestode Philobythos atlanticus and the trematode Glomericirrus macrouri, and on benthic animals which are connected with the trematode Gonocerca macrouri. The low incidence of some com- mon pelagic parasites (i.e. Scolex pleuronectis I., Derogenes varicus, Contracaecum aduncum and Anisakis $\mathrm{sp}$.) probably occurred during diurnal vertical migrations of roundnose grenadier to the thermocline zone, where infected intermediate hosts such as copepods, euphausiids, sagittae, ctenophores and cephalopods were eaten. However, infestation by these parasites may have occurred through feeding on benthic animals such as amphipods, decapods and polychaetes, which are also known intermediate hosts of these parasites. The greater incidence of infestation by parasites whose intermediate hosts are pelagic animals and infection by a variety of Myxosporidia suggest that pelagic animals form a significant part of the diet. These observations agree with the results of feeding studies on roundnose grenadier in the Northwest Atlantic (Konstantinov and Podrazhanskaya, 1972; Podrazhanskaya, 1971; Savvatimsky, MS 1969, 1970).

Differences in the incidence of certain parasites in roundnose grenadier were evident in the samples from the three areas (Table 1). Fish of the northern group 
(Davis Strait) were not infested by Myxidium melanocetum, but they were severely infested by Auerbachia pulchra ( $87 \%)$, moderately by Myxidium melanostigmum $(36 \%)$ and Philobythos atlanticus $(36 \%)$ and weakly by Gonocerca macrouri $(12 \%)$ and some other parasites. Fish of the southern group (northern Grand Bank) were less infested by Auerbachia pulchra $(51 \%)$ and Philobythos atlanticus $(20 \%)$ but more heavily infested by Myxidium melanostigmum (41\%), Gonocerca macrouri (27\%) and Glomericirrus macrouri (13\%). Spores of Myxidium melanocetum, absent in the northern group, were also found (19\%). Infestation of fish of the central group (Labrador) was generally intermediate with respect to the dominant parasites, except for Diclidophora macruri and Anisakis sp. which were more prevalent than in either the northern or southern group.

These north to south trends in parasite incidence appear to be related to fish size and age in that most of the $42-70 \mathrm{~cm}$ fish were severly infested by Auerbachia pulchra in the northern area whereas $65-85 \mathrm{~cm}$ fish were infested in the southern area. In the case of Gonocerca macrouri and Myxidium melanostigmum, the larger fish $(>65 \mathrm{~cm})$ in the southern area were more heavily infested than the smaller northern fish. Examination of the data for each area by time of sampling indicated a high degree of similarity in the patterns of infestation (Table 2), the most significant exceptions being a decline in the occurrence of Phillobythos atlanticus in Davis Strait in the last period and the absence of Anisakis sp. also in the last period. The observed changes in infestation of fish by a group of parasites is probably related to migration of the fish, as they grow, from the northern to the southern areas. This supposition is indirectly confirmed by the fact that fish from the southern area are in general larger (mode 69-74 $\mathrm{cm}$ ) than those from the northern area (mode 62-65 $\mathrm{cm}$ ). Similar ecologies of roundnose grenadier in the three areas are indicated by the fact that $50 \%$ of the parasites occurred in all three areas and that 7 of 8 parasites specific to roundnose grenadier (excluding only Myxidium melanocetum) were also present.

\section{Roughhead grenadler, Macrourus berglax}

Twenty species of parasites were found in the 30 specimens of roughhead grenadier examined (Table 3), of which seven parasites in three groups (Myxosporidia, Monogenoidea and Crustacea) have a direct life cycle. Trematoda (six species) was the most widely represented group. The incidence of infection on Flemish Cap was highest for Contracaecum aduncum (73\%) and somewhat lower for Echinorhynchus gadi (47\%), Clavella adurica (47\%) and Clavellomimus macruri (40\%). The dominant parasites off southern Labrador were Echinorhynchus gadi (73\%), Contracaecum aduncum (67\%), Genolinea laticauda (53\%) and Gonocerca crassa (53\%). Among the parasites found, four species (Davisia newfoundlandia, Zschokkella kudoi, Cyclocotyloides pinguis and Clavellomimus macruri) are specific to roughhead grenadier, and two species (Auerbachia pulchra and Philobythos atlanticus) are specific to deepwater fish. The remaining parasites are quite common in a large variety of hosts.

The parasitic fauna of roughhead grenadier from the two areas (Table 3 ) are very different, due possibly to living conditions at the different depths from which the samples were taken: $400-600$ m off southern Labrador and 1,200-1,400 $\mathrm{m}$ in the Flemish Cap area. The relatively few parasites in the Flemish Cap specimens

TABLE 2. Percentage infestation of roundnose grenadier, Coryphaenoides rupestrus, by time of capture and area in the Northwest Atlantic.

\begin{tabular}{|c|c|c|c|c|c|c|c|c|c|}
\hline \multirow[b]{2}{*}{ Parasite } & \multicolumn{3}{|c|}{ November-December 1974} & \multicolumn{3}{|c|}{ January 1975} & \multicolumn{3}{|c|}{ November-December 1975} \\
\hline & Davis St. & Labrador & Grand Bank & Davis St. & Labrador & Grand Bank & Davis St. & Labrador & Grand Bank \\
\hline Auerbachia pulchra & 86.7 & 48.8 & 60.0 & 93.3 & 40.0 & 40.0 & 80.0 & 50.0 & 53.3 \\
\hline Myxidium melanocetum & - & 4.4 & 16.7 & - & - & 20.0 & - & 6.6 & 20.0 \\
\hline Myxidium melanostigmum & 40.0 & 33.3 & 46.7 & 33.3 & 33.3 & 36.6 & 33.3 & 40.0 & 40.0 \\
\hline Myxidium profundum & 8.9 & 8.9 & 13.3 & 20.0 & 20.0 & 20.0 & 10.0 & 13.3 & 20.0 \\
\hline Zschokkella hildae & - & 2.2 & - & - & - & - & - & - & - \\
\hline Diclidophora macruri & 15.6 & 26.6 & 3.3 & 13.3 & 26.6 & - & 13.3 & 26.6 & - \\
\hline Philobythos atlanticus & 40.0 & 17.8 & 13.3 & 40.0 & 33.3 & 33.3 & 13.3 & 23.3 & 13.3 \\
\hline Pseudophyllidea gen. sp. & 2.2 & - & - & 6.6 & - & - & - & - & - \\
\hline Scolex pleuronectis I. & 2.2 & - & - & 13.3 & - & - & 6.6 & 6.6 & - \\
\hline Aporocotyle simplex & - & 2.2 & - & - & 3.3 & - & - & 3.3 & 3.3 \\
\hline Derogenes varicus & - & 2.2 & - & - & - & - & - & - & - \\
\hline Glomericirrus macrouri & 6.6 & 6.6 & 3.3 & 6.6 & 13.3 & 16.6 & 10.0 & 6.6 & 20.0 \\
\hline Gonocerca macroformis & - & 2.2 & - & - & - & - & - & - & - \\
\hline Gonocerca macrouri & 13.3 & 26.6 & 33.3 & 6.6 & 13.3 & 13.3 & 16.6 & 16.6 & 33.3 \\
\hline Anisakis sp. I. & 2.2 & 17.8 & 3.3 & - & 26.6 & - & 6.6 & - & 6.6 \\
\hline Contracaecum aduncum & 2.2 & - & - & - & - & - & - & - & - \\
\hline Contracaecum aduncum I. & 2.2 & 4.4 & 3.3 & - & - & - & - & 13.3 & 6.6 \\
\hline Chondracantus radiatus & - & 2.2 & - & - & - & 3.3 & - & - & - \\
\hline Clavella adunca & 4.4 & 6.6 & 3.3 & 6.6 & 13.3 & - & 6.6 & 6.6 & 6.6 \\
\hline No. of grenadier examined & 45 & 45 & 30 & 30 & 30 & 30 & 30 & 30 & 30 \\
\hline
\end{tabular}


TABLE 3. Parasitic fauna of roughhead grenadier, Macrourus berglax, in the Northwest Atlantic.

\begin{tabular}{|c|c|c|c|c|c|c|c|c|c|c|}
\hline \multirow[b]{3}{*}{ Parasites } & \multicolumn{5}{|c|}{ Flemish Cap (15 spec.) } & \multicolumn{5}{|c|}{ S. Labrador (15 spec.) } \\
\hline & \multicolumn{2}{|c|}{$\begin{array}{c}\text { Specimens } \\
\text { infested }\end{array}$} & \multicolumn{3}{|c|}{$\begin{array}{l}\text { Intensity of } \\
\text { infestation }\end{array}$} & \multicolumn{2}{|c|}{$\begin{array}{l}\text { Specimens } \\
\text { infested }\end{array}$} & \multicolumn{3}{|c|}{$\begin{array}{c}\text { Intensity of } \\
\text { infestation }\end{array}$} \\
\hline & No. & $\%$ & Min & Max & Mean & No. & $\%$ & Min & $\operatorname{Max}$ & Mean \\
\hline \multicolumn{11}{|l|}{ Myxosporidia } \\
\hline Auerbachia pulchra & 2 & 13.3 & + & + & + & 7 & 46.6 & + & + & + \\
\hline Davisia newfoundlandia & - & - & - & - & - & 1 & 6.6 & + & + & + \\
\hline Zschokkella kudoi & - & - & - & - & - & 4 & 26.6 & + & + & + \\
\hline \multicolumn{11}{|l|}{ Monogenoidea } \\
\hline Cyclocotyloides pinguis & 2 & 13.3 & 1 & 2 & 0.2 & - & - & - & - & - \\
\hline \multicolumn{11}{|l|}{ Cestoda } \\
\hline Philobythos atlanticus & - & - & - & - & - & 2 & 13.3 & 1 & 1 & 0.1 \\
\hline Pseudophyllidea gen. sp. & - & - & - & - & - & 1 & 6.6 & 3 & 3 & 0.2 \\
\hline Scolex pleuronectis I. & - & - & - & - & - & 3 & 20.0 & 1 & 20 & 2.3 \\
\hline \multicolumn{11}{|l|}{ Trematoda } \\
\hline Derogenes varicus & 2 & 13.3 & 1 & 1 & 0.1 & 2 & 13.3 & 1 & 2 & 0.2 \\
\hline Genolinea laticauda & - & - & - & - & - & 8 & 53.3 & 1 & 24 & 3.7 \\
\hline Gonocerca crassa & - & - & - & - & - & 8 & 53.3 & 1 & 6 & 1.5 \\
\hline Hemiurus levinseni & - & - & - & - & - & 1 & 6.6 & 1 & 1 & 0.1 \\
\hline Lepidapedon elongatum & - & - & - & - & - & 2 & 13.3 & 1 & 1 & 0.1 \\
\hline Lecithophyllum bothryophorum & - & - & - & - & - & 1 & 6.6 & 1 & 1 & 0.1 \\
\hline \multicolumn{11}{|l|}{ Nematoda } \\
\hline Anisakis sp. 1. & - & - & - & - & - & 2 & 13.3 & 1 & 6 & 0.5 \\
\hline Capillaria kabatai & - & - & - & - & - & 3 & 20.0 & 2 & 63 & 6.5 \\
\hline Contracaecum aduncum & 11 & 73.3 & 1 & 4 & 1.1 & 10 & 66.6 & 1 & 64 & 11.1 \\
\hline Contracaecum aduncum I. & - & - & - & - & - & 6 & 40.0 & 1 & 75 & 5.4 \\
\hline \multicolumn{11}{|l|}{ Acanthocephala } \\
\hline Echinorhynchus gadi & 7 & 46.6 & 2 & 8 & 2.0 & 11 & 73.3 & 1 & 48 & 11.8 \\
\hline \multicolumn{11}{|l|}{ Crustacea } \\
\hline Clavella adunca & 7 & 46.6 & 1 & 2 & 0.5 & 7 & 46.6 & 1 & 4 & 0.8 \\
\hline Clavellomimus macruri & 6 & 40.0 & 1 & 2 & 0.5 & 1 & 6.6 & 6 & 6 & 0.4 \\
\hline Rebelula bonvieri & 1 & 6.6 & 1 & 1 & 0.1 & 1 & 6.6 & 1 & 1 & 0.1 \\
\hline
\end{tabular}

indicates a restricted diet, composed of amphipods which are the intermediate hosts of Echinorhynchus gadi and various fish species which are the hosts of Contracaecum aduncum. Parasites common in fish from shallower depths were almost completely absent in the Flemish Cap specimens, indicating a high degree of isolation of these fish. The parasitic fauna of the southern Labrador specimens was more diverse, comprising six trematode species and other groups with a complex cycle of development, which indicates broad trophic relations among the fish of the area. Benthic animals (amphipods and polychaetes) and fish appear to be very important in the diet, as they are the intermediate hosts of Genolinea laticauda, Gonocerca crassa, Lepidapedon elongatum, Echinorphynchus gadi, Contracaecum aduncum, and possibly Derogenes varicus. According to Savvatimsky (MS $1969)$, fish (12-14\%), amphipods (13\%) and polychaetes $(5 \%)$ are important in the diet of roughhead grenadier from the Labrador area, and Geistdoerfer (1976) indicated that amphipods and polychaetes comprised 20 and $17 \%$ of the diet respectively. As indicated by the low incidence of Philobythos atlanticus, Scolex pleuronectis, Hemiurus levinseni and Anisakis $\mathrm{sp}$., pelagic animals which are intermediate hosts of these parasites are insignificant in the diet of roughhead grenadier. In view of the substantial qualitative and quantitative between-area differences in infestation by parasites, it is likely that there are at least two populations of roughhead grenadier in the areas investigated.

\section{Common grenadier, Nezumia bairdi}

Eleven species of parasites were found in the 23 specimens of common grenadier examined (Table 4), only two of which (Auerbachia pulchra and Myxidium profundum) have a direct life cycle. Trematoda and 
TABLE 4. Parasitic fauna of common grenadier, Nezumia bairdi, in the Northwest Atlantic.

\begin{tabular}{|c|c|c|c|c|c|c|c|c|c|c|}
\hline \multirow[b]{3}{*}{ Parasites } & \multicolumn{5}{|c|}{ Flemish Cap (16 spec.) } & \multicolumn{5}{|c|}{ S. Labrador (7 spec.) } \\
\hline & \multicolumn{2}{|c|}{$\begin{array}{c}\text { Specimens } \\
\text { infested }\end{array}$} & \multicolumn{3}{|c|}{$\begin{array}{l}\text { Intensity of } \\
\text { infestation }\end{array}$} & \multicolumn{2}{|c|}{$\begin{array}{c}\text { Specimens } \\
\text { infested }\end{array}$} & \multicolumn{3}{|c|}{$\begin{array}{l}\text { Intensity of } \\
\text { infestation }\end{array}$} \\
\hline & No. & $\%$ & Min & Max & Mean & No. & $\%$ & $\operatorname{Min}$ & $\operatorname{Max}$ & Mean \\
\hline \multicolumn{11}{|l|}{ Myxosporidia } \\
\hline Auerbachia pulchra & 1 & 6.2 & + & + & + & - & - & - & - & - \\
\hline Myxidium profundum & 6 & 37.5 & + & + & + & - & - & - & - & - \\
\hline \multicolumn{11}{|l|}{ Cestoda } \\
\hline Grillotia erinaceus I. & 3 & 18.8 & 1 & 6 & 0.8 & - & - & - & - & - \\
\hline Scolex pleuronectis I. & - & - & - & - & - & 7 & 100.0 & 12 & 83 & 34.4 \\
\hline \multicolumn{11}{|l|}{ Trematoda } \\
\hline Derogenes varicus & 1 & 6.2 & 1 & 1 & 0.1 & - & - & - & - & - \\
\hline Genolinea laticauda & - & - & - & - & - & 2 & 28.6 & 1 & 2 & 0.4 \\
\hline Glomericirrus macrouri & 1 & 6.2 & 1 & 1 & 0.1 & - & - & - & - & - \\
\hline \multicolumn{11}{|l|}{ Nematoda } \\
\hline Capillaria kabatai & 4 & 25.0 & 2 & 8 & 1.2 & 3 & 42.9 & 1 & 7 & 1.4 \\
\hline Contracaecum aduncum I. & 9 & 56.3 & 2 & 9 & 2.9 & 1 & 14.3 & 1 & 1 & 0.1 \\
\hline Terranova decipiens & - & - & - & - & - & 3 & 42.9 & 1 & 3 & 0.9 \\
\hline \multicolumn{11}{|l|}{ Acanthocephala } \\
\hline Echinorhynchus gadi & 1 & 6.2 & 2 & 2 & 0.1 & - & - & - & - & - \\
\hline
\end{tabular}

Nematoda (three species each) were the most widely represented groups. The incidence of infestation was highest for Contracaecum aduncum I. (50\%) in the Flemish Cap area and for Scolex pleuronectis I. (100\%) off southern Labrador.

The parasitic fauna of common grenadier from the two areas are quite different, due possibly to the different depths from which the specimens were taken: 400-450 m off southern Labrador and 1,100-1,130 $\mathrm{m}$ in the Flemish Cap area. However, in contrast to the pattern for roughhead grenadier, a greater varity of parasites occurred in specimens from Flemish Cap. Peculiarly, the Labrador specimens were infested only by those parasites with cycles of development related to planktonic organisms. Plankton is also an important part of the diet in the Flemish Cap area, as indicated by the high incidence of Contracaecum aduncum I., but they may also feed on benthos, as indicated by the occurrence of Echinorhynchus gadi. In general, the common grenadier may be considered as a typical plankton eater, as evidenced from the parasitic fauna. The between-area differences in infestation by parasites indicate that the samples were very likely from two separate populations of common grenadier.

\section{Chalimura brevibarbis}

One specimen of this species was caught in the Flemish Cap area, and spores of the myxosporidian Auerbachia pulchra were found in the gall bladder.

\section{References}

DOGIEL, V. A. 1933. Fish parasitology investigation problems (Methods and problems of ichthyoparasitological investigations). Trudy Len. Obshchestva Estestvoispytatelei, 62(2): 247-268.

GAYEVSKAYA, A. V., A. A. KOVALYOVA, and B. A. UMNOVA. 1980. Davisia amoena sp. n. (Myxosporidia: Sinulineidae), a parasite of fishes of the family Pleuronectidae from the Northwestern Atlantic. Parasitol., 14(3): 276-279.

GEISTDOERFER, P. 1976. Alimentation de deuse Macrouridae de l'Atlantique nord: Macrourus berglax et Coryphaenoides rupestris (Teleostei: Gadiformes) Rev. Trav. Inst. Peches Marit. Nantes, 40: 579-580.

KABATA, Z. 1969. Four Lernaeopodidae (Copepoda) parasitic on fishes from Newfoundland and West Greenland. J. Fish. Res. Bd. Canada, 26: 311-324.

KONSTANTINOV, K. G., and S. G. PODRAZHANSKAYA. 1972. Feeding and nutritional relations between rock grenadier (Macrourus rupestris) and other deepwater fishes of the Northwest Atlantic. Tr. Polyarn. Nauchno-Issled. Inst. Morsk. Rybn. Khoz. Okeanogr., 28: 96-106.

LOM, J., and M. LAIRD. 1976. Parasitic protozoa from marine and euryhaline fish of Newfoundland and New Brunswick. II. Microsporidia. Trans. Am. Microsc. Soc., 95: 569-580.

LOM, J., E. R. NOBLE, and M. LAIRD. 1975. Myxosporidia from the deep-sea fish, Macrourus berglax, off Newfoundland and Iceland. Folia Parasitol., 22: 105-109.

MOSER, M. 1977. Meglitch's hypothesis: a critical evaluation. Folia Parasitol., 24: 177-178.

MOSER, M., and E. R. NOBLE. 1977a. Myxosporidia genera Auerbachia, Sphaerospora, Davisia and Chloromyxum in macrourid fishes and the sablefish, Anoplopoma fimbria. Z. Parasitenk., 51: 159-163.

1977b. Zschokkella (Protozoa: Myxosporidia) in macrourid fishes. Int. J. Parasitol., 7: 97-100.

PODRAZHANSKAYA, S. G. 1971. Feeding and migrations of the 
roundnose grenadier (Macrourus rupestris) in the Northwest Atlantic and Iceland waters. ICNAF Redbook 1971, Part III: 115-123.

SAVVATIMSKY, P. I. MS 1969. Roundnose grenadier of the North Atlantic. PINRO, Murmansk, 72 p. (In Russian).

1970. Feeding and vertical distribution of the roundnose grenadier. Mater. Rybokhoz Issled. Sev. Bass., 16: 177-187.

SZUKS, H. 1975. Zum Befall von Macrourus rupestris (Gunnerus) aus dem Bereich von Labrador mit digenen Trematoden. Wiss. Z. Pad. Hochsch. "Liselotte Hermann." Gustrow, Math.-Naturwiss. Fak., 2: 225-231.

TEMPLEMAN, W., and H. J. SQUIRES. 1960. Incidence and distribution of infestation of Sphyrion lumpi (Krфyer) on the redfish Sebastes marinus (L.) of the western North Atlantic. J. Fish. Res. Bd. Canada, 17: 9-31.
WILSON, C. B. 1920. North American parasitic copepoda belonging to the new family Sphyriidae. Proc. U.S. Natl. Mus., 55: 549-604.

YOSHINO, T. P., and E. R. NOBLE. 1973. Myxosporidia in macrourid fishes of the North Atlantic. Can. J. Zool., 51: 745-752.

ZUBCHENKO, A. V. 1976. On existence of a single population of rock grenadier (Macrourus rupestris Gunnerus) in the Northwest Atlantic in the light of parasitologic data. Kr. Tez. Dokl. II Vsesoyuzn. Sympos. po Parazitam i Bolezn. Ryb. i Morsk. Zhlvotn. Kaliningrad: 29-30.

1981. Myxidium profundum Zubtschenko 1981 (Myxosporidia: Myxidlidae) - a new name for M. noblei Zubtschenko 1980. Parasitol., 15: In press.

ZUBCHENKO, A. V., AND V. K. KRASIN. 1980. Myxosporidia of the genus Myxidium in some macrourids from northern Atlantic and Pacific. Parasitol., 14: 168-176. 